\title{
Effect Of Temperature And Storage Time On The Nutritional Quality Of Olive Drupes: A Case Study
}

\author{
E. Finotti, L. Gambelli, G. M. Mili, G. Lo Feudo, C. Benincasa, M. Pellegrino, and E. Perri
}

\begin{abstract}
In this study we evaluated the effect of temperature and time storage on the quality parameters of mono cultivar olive oil drupes. In particular, analyses of total free phenols, fatty acids, lipophilic and hydrophilic antioxidant capacity, sensory analysis, at different temperatures and different times of post harvest storage, were performed. All data obtained have been singularly processed by Functional Mathematical Index (FMI).
\end{abstract}

Index Terms - Functional Mathematical Index, nutritional quality, olive oil storage, sensory analysis temperature.

\section{INTRODUCTION}

The olive oil is an important product in the Italian traditions dishes and it is also peculiar in the Mediterranean diet. The production of this food is very ancient and the first archaeological artifacts, that testify its production, are dating back 2500 B.C. [1]. The Mediterranean area remains the most important production place, even if today other geographical area are starting to produce this food [2].

During the years 2011 and 2012, about $80 \%$ of the total olive oil has been produced in the European Union of which $77 \%$ has been produced in Spain, Italy and Greece [3]-[4].

Due to his high nutritional value, the main use of olive oil is as ingredient in different foods, and nowadays, also for pharmaceutical and cosmetological preparations [5].

During the last years, several studies underlined the healthy properties of olive oil in human diet.

The nutrient characteristics of extra virgin olive oil are well known and are due to the high content of monounsaturated fatty acids and the presence of minor compounds with antioxidant activity. The use of extra virgin olive oil is important in human diet because it seems to show a protective action on cancers, heart attack, ateriosclerosis and aging processes. In 2004 the Food and

Published on July 1, 2020.

E. Finotti, CREA Research Centre for Food and Nutrition, Italy. (corresponding e-mail: enrico.finotti@ crea.gov.it).

L. Gambelli, CREA Research Centre for Food and Nutrition, Italy.

(e-mail: loretta.gambelli@ crea.gov.it ).

G. M. Mili, CREA Research Centre for Food and Nutrition, Italy.

(e-mail: gioia.mili@gmail.com).

G. Lo Feudo, CREA Research Centre for Olive, Citrus and Tree Fruit, Italy.

(e-mail: gabriella.lofeudo ${ }^{\circledR}$ crea.gov.it).

C. Benincasa, CREA Research Centre for Olive, Citrus and Tree Fruit, Italy.

(e-mail: cinzia.benincasa ${ }^{@}$ crea.gov.it).

M. Pellegrino, CREA Research Centre for for Olive, Citrus and Tree Fruit, Italy.

(e-mail: massimiliano.pellegrino@ crea.gov.it )

E. Perri, CREA Research Centre for Food and Nutrition, Italy.

(e-mail: enzo.perri@crea.gov.it).
Drugs Administration remarked the role played of monosaturated fatty acids against the cardiovascular disease [6].

Other studies showed that the use of olive oil in human nutrition prevents the Low Density Lipoprotein (LDL) [7] contributing to increase the High Density Lipoprotein in the human serum [8]. This is because olive oil has a perfect ratio between saturated and unsaturated fatty acids.

It is well know the high energy value of olive oil and from a nutritional point of view, present also a good ratio between saturated and unsaturated fatty acids. Moreover, the presence of minor compounds, such as phenols and tocopherols that contribute to the antioxidant capacity, olive oil increase its own healthy value [9]-[12]. Thanks to these compounds, olive oil play an important role in the human energy requirement, in particular in striated muscle, as they contribute to the transport of lipovitamin A, D, E, K [13].

Several studies have, also, showed the protective action of olive oil against cancer, cardiovascular disease and aging [14]-[16].

Pedoclimatic conditions, cultivar, harvesting methods, maturation grades of drupes, processing methods, all influence the quality of the olive oil.

During maturation, the cell wall of olive drupe, undergoes to different chemical and physic changes [17]. leading to the decrease of antioxidant compounds [18]-[22] that affects the nutritional value of the final oil. The most common problem is to preserve the nutritional quality of the olive oil along its extraction processes and, in particular, the drupes storage [23]. This latter, is not just a logistic problem but, it is a very important step in the entire olive oil process, in fact a not adequate drupes storage would compromise the final product, decreasing the chemical, the nutritional and the organoleptic quality of the oil produced.

To preserve the quality of the oil, olive drupes have to be placed in suitable containers in order to reduce chemical degrades and fermentative/oxidative processes and, immediately processed after the harvest.

Long periods of storage in poorly ventilated bags or heaps piled on the ground, long times of crushing by means of mechanical blades, compromise the integrity of the fruits and then the quality of the final product. Also, the temperature plays an important role during the storage; in fact, temperatures up to $7.5{ }^{\circ} \mathrm{C}$ increase microbial growth and fermentative processes with related decrease of nutritional quality of the oil [24]-[25]. In particular, the fermentations is responsible for "heat" and in extreme cases "molds" defects.

The food organoleptic characteristics are important parameters for its overall assessment and are essential to satisfy the consumer. In fact, the volatile compounds, 
present in olive oil, contributes to the taste perception, which makes it unique and also includes part of its nutraceutical characteristics.

Post-harvest step is a not a well studied topic, but, it is very important because in every geographical area producers tend to collect drupes at the same time, creating what we call "funnel effect". This effect occurs in the post-harvest period when the loss of important nutritional molecules occur. So, the aim of this study is "how long can drupes be stored before processing them?"

The purpose of this experimental trial was, therefore, to verify, through chemical and sensory analysis, the maximum time that olives can be stored before being processed in the mill to avoid the appearing of sensory defects. In particular, analyses of fatty acids, phenols, lipophilic/hydrophilic antioxidant capacities and sensory analysis were carried out on oil samples from "Carolea" cultivar, a typical variety of Calabria [26]-[29]. This cultivar is present throughout the territory, in particular, it is very present in the province of Catanzaro, partly present in Cosenza and less present in Reggio Calabria. The Carolea drupe is rather large and has a dual attitude although it is mainly intended for the production of high quality oil. The results obtained in this case study may be useful for small olive-oil-producing enterprises as well as increase the knowledge of this important olive cultivar [27]-[29]. The drupes have been stored at different temperature and at different storage times and then processes by using a laboratory scale mill equipment. All data have been processed by a Functional Mathematic Index in order to identify the best temperature and storage time.

\section{METHODOLOGY}

\section{A. Samples Collection}

Olives $(64 \mathrm{~kg})$ from Carolea cultivar were collected and placed in open boxes in October, during the crop year 2016 from plants belonging to the olive grove of Roberti Company located in Conflenti (CZ) a city of the southern Italian region, Calabria.

\section{B. Phytosanitary conditions of the drupes}

In order to verify the phytosanitary conditions of the drupes and to check a possible Bactrocera Oleae (olive fly) infestation, one hundred drupes were monitored. The score has been 4 larvae, 8 galleries/flickering/re-infest/reflickering, 6 pupae, 40 sterile stings and 42 flickered galleries.

\section{Samples and labeling partition}

All the harvested drupes were sampled and labeled as following:

Sample Control. Consisted of $14 \mathrm{~kg}$ of olives harvested and milled traigh after their harvest. On 100 drupes, the colour of 10 olives was green, the colour of 80 olives was yellow green and the colour of 10 olives was green with red spots.

Sample T. $25^{\circ} \mathrm{C}, 4 \mathrm{~d}$. The olives $(13 \mathrm{~kg})$ were stored at room temperature for $4 \mathrm{~d}$ and then milled. On 100 drupes, the colour of 10 olives was green, the colour of 80 olives was yellow green and the colour of 10 olives was green with red spots.
Sample T. $9^{\circ} \mathrm{C}, 4$ days $(\mathrm{d})$. The olives $(13 \mathrm{~kg})$ were stored at $9^{\circ} \mathrm{C}$ for $4 \mathrm{~d}$ and then milled. On 100 drupes, the colour of 10 olives was green, the colour of 80 olives was yellow green and the colour of 10 olives was green with red spots.

Sample T. $25^{\circ} \mathrm{C}, 9 \mathrm{~d}$. The olives $(12 \mathrm{~kg})$ were stored at room temperature for $9 \mathrm{~d}$ and then milled. On 100 drupes, the colour of 10 olives was green, the colour of 80 olives was yellow green and the colour of 10 olives was green with red spots.

Sample T. $9^{\circ} \mathrm{C}, 9 \mathrm{~d}$. The olives $(12 \mathrm{~kg})$ were stored at $9{ }^{\circ} \mathrm{C}$ for $9 \mathrm{~d}$. On 100 drupes, the colour of 10 olives was green, the colour of 80 olives was yellow green and the colour of 10 olives was green with red spots.

\section{Total free phenols}

Each sample has been extracted three times with a watermethanol solution $(50: 50 \mathrm{v} / \mathrm{v})$. The solution has been dried by vacuum evaporation at $40{ }^{\circ} \mathrm{C}$ and stored under vacuum at $4{ }^{\circ} \mathrm{C}$. The dried sample has been dissolved with $0.5 \mathrm{~mL}$ of water-methanol solution and analysed by means of a spectrophotometer at $756 \mathrm{~nm}$ according to Folin-Ciocolteau method [30]. The amount of total phenols has been detected, comparing, for each sample, the results found with a standard solution of caffeic acid.

\section{E. Hydrophilic and lipophilic antioxidant capacity}

The antioxidant capacity of lipophilic extracts was estimated by crocin bleaching inhibition method [31]-[33]. This method is based on the crocin bleaching as a result of its oxidation by a source of radicals, [2,20-Azobis $(2,4-$ dimethyl)valeronitrile] (AMVN). The reaction is monitored by recording, for ten minutes, the corresponding decrease of absorbance at $443 \mathrm{~nm}$. The reaction with the crocin alone gives us the bleaching rate $\mathrm{V} 0$ and when an antioxidant or pseudoantioxidant is added it reacts with the free radicals and, as a consequence, the crocin bleaching rate ( $\mathrm{Va}$ ) is reduced, according to the competitive reaction equation:

$$
\frac{V o}{V a}=1+\frac{\mathrm{Ka}}{\mathrm{Kc}} \times \frac{[\text { Pescudo }- \text { antioxidant }]}{[\text { Crocin }]}
$$

where $\mathrm{Kc}$ and $\mathrm{Ka}$ are the respective absolute second order constants. The slope $\mathrm{Ka} / \mathrm{Kc}$ has been calculated by means of the [Pseudo-antioxidant]/[crocin] versus V0/Va linear regression plot. Its value indicates the relative capacity (antioxidant capacity) of different molecules to interact with the ROO- radicals. The AMVN $(40 \mathrm{mM})$ and crocin $(0.24 \mathrm{mM})$ were added to the toluene extract and bleaching rate of crocin was determined after $10 \mathrm{~min}$ from the beginning of the reaction. The reaction was carried out at $40{ }^{\circ} \mathrm{C}$. Blank without sample was run to rule out spectral interferences between compounds and crocin. All lipophilic extracts corresponding to each millstream under investigation were tested. Each kinetic analysis was compared with kinetic crocin bleach containing only AMVN (with bleaching rate V0) and used for the calculations according to the competitive reaction equation. The same method was used for the measurement of the hydrophilic antioxidant capacity, using the APAB [2,20-Azobis(2methylpropionamidine) dihydrochloride] as free radical source [31]-[34]. Solvents were from Sigma Aldrich (Mi, Italy). AMVN and APAB were from Waco Chem 
(Richmond, VA, USA).

\section{F. Fatty Acids}

Fatty acid composition was analyzed by gas chromatography [32]-[35]. Briefly, $2 \mathrm{~g}$ of oil were extracted with $10 \mathrm{~mL}$ chloroform/methanol $(2: 1 \mathrm{v} / \mathrm{v})$ and $100 \mu \mathrm{l}$ were evaporated to dryness by nitrogen, transmethylated by boron trifluoride (BF3) and heated under reflux with methanol at $72{ }^{\circ} \mathrm{C}$ for $30 \mathrm{~min}$. The obtained methyl esters were extracted with n-hexane and evaporated by nitrogen to dryness. Transmethylated samples were performed in duplicate and, $1 \mu \mathrm{l}$ of each sample solute in n-hexane, was injected.

\section{G. Organoleptic analysis}

The olive oils produced in the experimental trial were evaluated by sensory analyses in order to estimate their organoleptic characteristics according to the Regulation No. 2568/91 and subsequent amendments and additions [36].

\section{H. FMI (Functional Mathematical Index)}

This index introduces the concept of "optimal product" by applying the Euclidean standard (modified) to a vector of a dimensional $\mathrm{N}$-parameters in space. Where $\mathrm{N}$ is the number of selected parameters, which are normalized and then added together [37]-[42], Since this index is able to processes not only continuous numeric value, but also discontinuous numerical value, such as the organoleptic results, and in order to use this results in the FMI score, we decided to consider the bitter, spicy and fruity as positive characteristics, on the contrary heat and mold as negative characteristics, assigning at each of them the value of one (i.e. if we have 3 positive characteristics such as bitter, spicy and fruity, and each of them value is one, the final score will be 3$)$.

\section{Statistics}

The data reported represent the mean value obtained by performing the experiments in triplicate. The statistical variations were evaluated by Student's t-distribution $(\mathrm{p}>0.05)$.

\section{RESULT AND DISCUSSION}

\section{A. Total Phenols}

Table I list the amount of total phenols contained in the samples under investigations. It is possible to observe that the concentration values of phenols decrease. However, there is no statistically significant differences $(p<0,05$, $\mathrm{P}=0,3294)$. From these results we can say that, in the sample studied, the temperature and storage do not influence the phenols production.

\begin{tabular}{lcc}
\multicolumn{3}{c}{ TABLE I: Total POLYPHENOLS } \\
\hline Samples & $\mathrm{mg} \mathrm{kg}^{-1}$ & \pm \\
\hline Control & 218,26 & 20,00 \\
\hline T. $25^{\circ} \mathrm{C}, 4 \mathrm{~d}$ & 273,06 n.s. & 19,50 \\
\hline T. $9^{\circ} \mathrm{C}, 4 \mathrm{~d}$ & 253,35 n.s. & 21,30 \\
\hline T. $25^{\circ} \mathrm{C}, 9 \mathrm{~d}$ & 190,49 n.s. & 17,20 \\
\hline T. $9{ }^{\circ} \mathrm{C}, 9 \mathrm{~d}$ & 228,20 n.s. & 20,40
\end{tabular}

All values are the mean of three replicates, n.s. $=$ not significative, $*=$ $\mathrm{p}<0,05$.

\section{B. Lipophilic and hydrophilic antioxidant capacity}

Tables II a shows the lipophilic antioxidant capacity. From the result listed in the Table, it can be observed that the lipophilic antioxidant capacity does not decrease at $25^{\circ} \mathrm{C}$ after $4 \mathrm{~d}$ of storage $(\mathrm{P}=0.9378)$. Instead, it can be noted a remarkable reduction of it when the sample is stored at $9{ }^{\circ} \mathrm{C}(\mathrm{P}=0.0151)$. After $9 \mathrm{~d}$ of storage, the sample kept at $25{ }^{\circ} \mathrm{C}$ showed the same antioxidant capacity then the sample kept at $9{ }^{\circ} \mathrm{C}$ for $4 \mathrm{~d}(\mathrm{P}=0.0237)$ and, the sample kept at $9{ }^{\circ} \mathrm{C}$ for $9 \mathrm{~d}(\mathrm{P}=0.0004)$ does not showed any antioxidant capacity. The hydrophilic antioxidant capacity is reported in Table II b. Again, the samples stored at $25^{\circ} \mathrm{C}$ for $4 \mathrm{~d}$ show a slight difference respect to the control $(\mathrm{P}=0.4135)$, but at $9{ }^{\circ} \mathrm{C}$ the value reaches about half of sample control $(\mathrm{P}=0.0131)$. After $9 \mathrm{~d}$ of storage, a decrease of hydrophilic antioxidant capacity value in both samples kept at $25{ }^{\circ} \mathrm{C}$ $(\mathrm{P}=0.0151)$ and at $9{ }^{\circ} \mathrm{C}$ has been recorded but, in this last sample the decrease is not statistically significant $(\mathrm{P}=0.0770)$ and its value is similar to the sample kept at $9{ }^{\circ} \mathrm{C}$ for $4 \mathrm{~d}$.

\begin{tabular}{lcc}
\multicolumn{3}{c}{ TABLE II A: LIPOPHILIC ANTIOXIDANT CAPACITY } \\
\hline Samples & $\mathrm{Ka} / \mathrm{Kc}$ & \pm \\
\hline Control & 0,34 & 0,05 \\
\hline T. $25^{\circ} \mathrm{C}, 4 \mathrm{~d}$ & 0,35 n.s. & 0,13 \\
\hline T. $9{ }^{\circ} \mathrm{C}, 4 \mathrm{~d}$ & $0,15^{*}$ & 0,06 \\
\hline T. $25^{\circ} \mathrm{C}, 9 \mathrm{~d}$ & $0,16^{*}$ & 0,07 \\
\hline T. $9{ }^{\circ} \mathrm{C}, 9 \mathrm{~d}$ & $0 *$ & 0,1
\end{tabular}

All values are the mean of three replicates, n.s. $=$ not significative, $* *$ $\mathrm{p}<0,05$.

TABLE II B: HYDROPHILIC ANTIOXIDANT CAPACITY

\begin{tabular}{|c|c|c|}
\hline Sample & $\mathrm{Ka} / \mathrm{Kc}$ & \pm \\
\hline T. $25^{\circ} \mathrm{C}, 0 \mathrm{~d}$ & 0,68 & 0,15 \\
\hline T. $25^{\circ} \mathrm{C}, 4 \mathrm{~d}$ & 0,58 n.s. & 0,11 \\
\hline T. $9^{\circ} \mathrm{C}, 4 \mathrm{~d}$ & $0,35 *$ & 0,16 \\
\hline T. $25^{\circ} \mathrm{C}, 9 \mathrm{~d}$ & $0,44 *$ & 0,18 \\
\hline T. $9^{\circ} \mathrm{C}, 9 \mathrm{~d}$ & 0,39 n.s. & 0,15 \\
\hline
\end{tabular}

All values are the mean of three replicates, n.s. $=$ not significative,$*=$ $\mathrm{p}<0,05$.

\section{Fatty acids}

Table III shows the most representative fatty acids present in the oil, in which oleic acid, palmitic acid and stearic acid, are the most representative fatty acids. Palmitic acid values do not present differences vary in each sample tested. Oleic acid decreases during the time between the forth and the ninth day, and, only in the last period, its value decreases significantly $\left(25{ }^{\circ} \mathrm{C} 9 \mathrm{~d} \mathrm{P}=0.063\right.$, and $\left.9{ }^{\circ} \mathrm{C} 9 \mathrm{~d} \mathrm{P}=0.0002\right)$. Stearic acid increases its concentration from the fourth day to the ninth day $\left(25^{\circ} \mathrm{C} 4 \mathrm{~d} \mathrm{P}=0.0001,9 \mathrm{C}^{\circ} 4 \mathrm{~d} \mathrm{P}=0.0004\right.$, $\left.25^{\circ} \mathrm{C} 9 \mathrm{~d} \mathrm{P}=0.0001,9^{\circ} \mathrm{C} 9 \mathrm{~d} \mathrm{P}=0.0001\right)$, miristic acid $\left(25^{\circ} \mathrm{C}\right.$ $4 \mathrm{~d} \mathrm{P}=0.0001,9{ }^{\circ} \mathrm{C} 4 \mathrm{~d} \mathrm{P}=0.0001,25^{\circ} \mathrm{C} 9 \mathrm{~d} \mathrm{P}=0.0002,9{ }^{\circ} \mathrm{C}$ $9 \mathrm{~d} \mathrm{P}=0.0001)$ and linoleic acid $\left(25^{\circ} \mathrm{C} 4 \mathrm{~d} \mathrm{P}=0.0001,9{ }^{\circ} \mathrm{C} 4\right.$ $\mathrm{d} \mathrm{P}=0.0001,25{ }^{\circ} \mathrm{C} 9 \mathrm{~d} \mathrm{P}=0.0001,9{ }^{\circ} \mathrm{C} 9 \mathrm{~d} \mathrm{P}=0.0001$ ) are present at low concentrations and their trend is very similar along all the storage time.

In the fatty acid profile (Table III) we can observe a common fatty acids pattern of the olive oil, but the most important differences are due to oleic acid, that decreases 
during the time between the forth and the ninth day and to Linoleic acid, that in the last period, its value decreases significantly. In our opinion this parameter does not seems related to the temperature, but to the storage time. On the contrary Stearic acid increases its concentration from the fourth day to the ninth day, also in this case it own trend does not seem related to the temperature.

TABLE III: FATTY ACIDS (\%)

\begin{tabular}{|c|c|c|c|c|c|c|c|c|c|c|}
\hline Samples & $\mathrm{C} 14: 0$ & $\pm \mathrm{SD}$ & $\mathrm{C} 16: 0$ & $\pm \mathrm{SD}$ & $\mathrm{C} 18: 0$ & $\pm \mathrm{SD}$ & $\mathrm{C} 18: 1$ & $\pm \mathrm{SD}$ & $\mathrm{C} 18: 2$ & $\pm \mathrm{SD}$ \\
\hline Control & 6.0 & 0,4 & 31,8 & 2,9 & 11,5 & 0,9 & 50,7 & 3,5 & 4,33 & 0,25 \\
\hline $25^{\circ} \mathrm{C}, 4 \mathrm{~d}$ & $1,9 *$ & 0,15 & 30,5 n.s & 2,5 & $27,2 *$ & 1,1 & 40,3 n.s. & 3,7 & $0.0 *$ & 0.0 \\
\hline $9^{\circ} \mathrm{C}, 4 \mathrm{~d}$ & $2.0 *$ & 0,18 & 26,6 n.s. & 2,4 & $22,9 *$ & 1,5 & 48,3 n.s. & 3,2 & $1,14 *$ & 0,09 \\
\hline $25^{\circ} \mathrm{C}, 9 \mathrm{~d}$ & $2,6 *$ & 0,15 & 28,4 n.s & 2,5 & $32,3 *$ & 1,3 & $36,7 *$ & 3.0 & $0.0 *$ & 0.0 \\
\hline $9^{\circ} \mathrm{C}, 9 \mathrm{~d}$ & $2,4 *$ & 0,16 & 36,7 n.s. & 2,2 & $37,2 *$ & 1,8 & $22,7 *$ & 1,4 & $0.0 *$ & 0.0 \\
\hline
\end{tabular}

All values are the mean of three replicates, n.s. $=$ not significative, $*=p<0,05$.

\section{Organoleptic analysis}

Sensory analysis is reported in Table IV. Sample Control: the organoleptic examination of the oil highlighted a light green fruity; a slight hint of bitter and spicy with a persistence of the bitter and a light aftertaste of sweet almonds.

Sample kept at $25{ }^{\circ} \mathrm{C}$ for $4 \mathrm{~d}$ : the organoleptic examination of the oil highlighted a slight fruity. The bitter and spicy were light and the persistence of the spicy exceeded the one of the bitter. Sample kept at $9{ }^{\circ} \mathrm{C}$ for $4 \mathrm{~d}$ : the organoleptic examination showed a medium fruity of green olives with persistent spicy and bitterness. A definite aftertaste of almond and artichoke was perceived. Sample kept at $25^{\circ} \mathrm{C}$ for $9 \mathrm{~d}$ : the organoleptic examination showed a complete absence of fruity with defects of mold and heat that were perceptible to the nose and markedly to the taste.

Sample kept at $9{ }^{\circ} \mathrm{C}$ for $9 \mathrm{~d}$ : the organoleptic examination showed a light fruity with an aftertaste of heat and mold.

In order to use this results in the FMI score, we decided to consider the bitter, spicy and fruity as positive characteristics (+), on the contrary heat and mold as negative characteristics (-), assigning at each of them the value of one (i.e. if we have 3 positive characteristics such as bitter, spicy and fruity, and each of them value is one, the final score will be 3). The increase of storage time increases the negative attributes, regardless the storage temperatures.

In according with the data reported in Table 4, in the organoleptic analysis the positive caracteristics decrease with the storage time and increse the negative caracteristics, untill the complete absence of fruity with defects of mold and heat that were perceptible to the nose and markedly to the taste.

In our opinion, probably, the samples kept at $25^{\circ} \mathrm{C}$ are more airy and for this reason the fermentative processes are more mitigate because this environment present a low humidity content, how also underline by the sensory analysis and the fatty acids profile. Instead the sample kept at $9{ }^{\circ} \mathrm{C}$, in a very closed environment, in which is more difficult remove the humidity and so to create a more suitable environment for microbial growth. However for all samples the storage time $(4 \mathrm{~d})$ appear a critical point for nutritional quality drupes.
TABLE IV: ORGANOLEPTIC ANALYSIS

\begin{tabular}{lcc}
\hline Samples & Positive characteristics & Negative characteristics \\
\hline $25^{\circ} \mathrm{C}, 0 \mathrm{~d}$ & 3 & 0 \\
\hline $25^{\circ} \mathrm{C}, 4 \mathrm{~d}$ & 3 & 0 \\
\hline $9^{\circ} \mathrm{C}, 4 \mathrm{~d}$ & 2 & 0 \\
\hline $25^{\circ} \mathrm{C}, 9 \mathrm{~d}$ & 0 & 2 \\
\hline $9^{\circ} \mathrm{C}, 9 \mathrm{~d}$ & 1 & 2 \\
\hline
\end{tabular}

All values are the mean of three replicates, n.s. $=$ not significative, ${ }^{*}=$ $\mathrm{p}<0,05$.

\section{E. FMI score}

Table V reports the Total and Local FMI scores obtained. The total FMI score, in all tested samples, falls in to the range between 0 and 1 ; where 0 indicates the best quality and 1 the worst one. In this study the best quality was found in the sample kept at $25{ }^{\circ} \mathrm{C}$ for $4 \mathrm{~d}$ (Total FMI score 0.45 ) and the worst one in the sample kept at $9{ }^{\circ} \mathrm{C}$ for $9 \mathrm{~d}$ (Total FMI score 0.85). Fig. 1 reports the Total FMI trend.

The FMI analysis has been performed in order to obtain an index able to integrate all the results obtained and to give a complete response about the processes in fact in Figure 1, it is possible to observe that both trends are very similar, but, the sample kept at $25{ }^{\circ} \mathrm{C}$ presents a best Total FMI score, that means a best nutritional quality. The increase of storage time increases the negative attributes and the fatty acids patter, regardless the storage temperatures.

TABLE V: TOTAL AND LOCAL FMI SCORES

\begin{tabular}{l|c|c|c|c|c}
\hline Parameters & $\begin{array}{c}25^{\circ} \mathrm{C} \\
0 \mathrm{~d}\end{array}$ & $\begin{array}{c}25^{\circ} \mathrm{C} \\
4 \mathrm{~d}\end{array}$ & $\begin{array}{c}9{ }^{\circ} \mathrm{C} \\
4 \mathrm{~d}\end{array}$ & $\begin{array}{c}25^{\circ} \mathrm{C} \\
9 \mathrm{~d}\end{array}$ & $\begin{array}{c}9{ }^{\circ} \mathrm{C} \\
9 \mathrm{~d}\end{array}$ \\
\hline Total FMI score & 0,65 & 0,45 & 0,59 & 0,70 & 0.85 \\
\hline Lipophilic antioxidant capacity & 0 & 0 & 0,11 & 0,09 & 1 \\
\hline Hydrophilic antioxidant Capacity & 0 & 0,01 & 1 & 0,28 & 0,60 \\
\hline Poliphenols & 0,19 & 0 & 0 & 1 & 0,09 \\
\hline C14:0 & 1 & 1 & 0,82 & 0,19 & 0,33 \\
\hline C16:0 & 0 & 0,01 & 1 & 0,25 & 1 \\
\hline C18:0 & 1 & 0 & 0 & 0,15 & 1 \\
\hline C:18:1 & 1 & 0 & 0,47 & 0 & 1 \\
\hline C18:2 & 1 & 1 & 0,05 & 1 & 1 \\
\hline Positive characteristics & 0 & 0 & 0,01 & 1 & 0,20 \\
\hline Negative characteristics & 0 & 0 & 0 & 1 & 1 \\
\hline
\end{tabular}




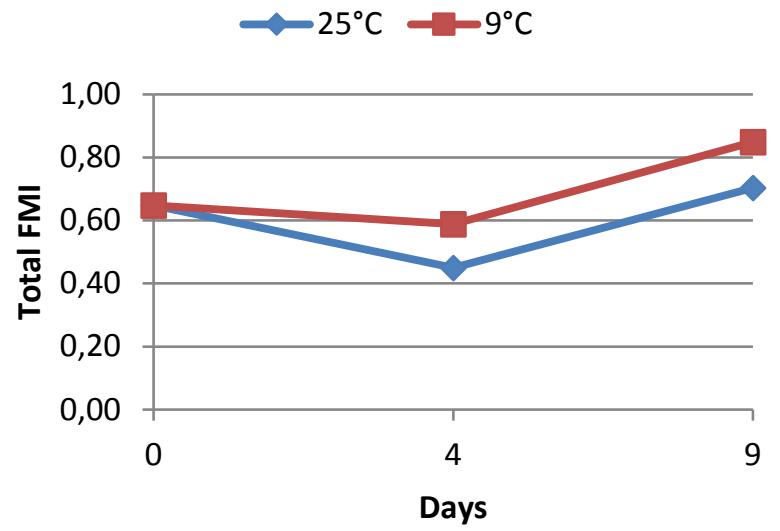

Fig. 1 Total FMI scores

\section{CONCLUSION}

In our opinion, probably, the samples kept at $25{ }^{\circ} \mathrm{C}$ are more airy and for this reason the fermentative processes are more mitigate because this environment present a low humidity content, how also underline by the sensory analysis and the fatty acids profile. Instead the

sample kept at $9{ }^{\circ} \mathrm{C}$, in a very closed environment, in which is more difficult remove the humidity and so to create a more suitable environment for microbial growth. However, for all samples the storage time (4 d) appear a critical point for nutritional quality drupes.

In conclusion the temperature and the storage time play important role in the nutritional quality of drupes, and by the FMI it is possible monitoring the storage processes.

\section{REFERENCES}

[1] Di Giovacchino L. Handbook of Olive Oil 2nd ed. Springer Science \& Business Media New York USA 2013. pp. 57-96.

[2] Ryan D., Robards K. (1998) Phenolic compounds in olives. Analyst. 123:31R-44R.

[3] European Commission (2012) Olive oil farms report. Brussels, February. Unit L3 D.

[4] Coz A., Villegas M., Andres A., Viguri J., Mantzavinos D., Xekoukoulotakis N. Management scenarios for olive oil mill based on characterization and leaching test. J. of Chemical Technology and Biotechnology. Vol. 89, 1542-1547, 2011.

[5] Mota A.H., Silva C.O., Nicolai M., Baby A., Palma L., Rijo P., Ascensao L., Reis C.P., Design and evaluation of novel topical formulation with olive oil as natural functional active. Pharm Dev Technol. Vol 23, 8, pp. 794-805, 2018.

[6] Ghanbari, R., Anwar, F., Alkharfy, K. M., Gilani, A.-H., \& Saari, N. Valuable Nutrients and Functional Bioactives in Different Parts of Olive (Olea europaea L.). A Review; International Journal of Molecular Sciences. Vol 13 (3), pp. 3291-3340, 2012.

[7] Marrugat J, Covas MI, Fitó M, Schröder H, Miró-Casas E, Gimeno E, López-Sabater MC, de la Torre R, Farré M; (2004) Effects of differing phenolic content in dietary olive oils on lipids and LDL oxidation a randomized controlled trial. SOLOS Investigators. Eur. J. Nutr. Vol. 43, 3, pp. 140-147, 2004.

[8] Hernáez Á, Remaley AT, Farràs M, Fernández-Castillejo S, Subirana I, Schröder H, Fernández-Mampel M, Muñoz-Aguayo D, Sampson M, Solà R, Farré M, de la Torre R, López-Sabater MC, Nyyssönen K, Zunft HJ, Covas MI, Fitó M. J., Olive Oil Polyphenols Decrease LDL Concentrations and LDL Atherogenicity. Men in a Randomized Controlled Trial. Aug. Vol 145(8), pp. 1692-1697, 2015.

[9] Lupinacci S., Toteda G., Vizza D., Perri A., Benincasa C, Mollica A., La Russa A., Gigliotti P., Leone F., Lofaro D., Bonoiglio M., Perri E., Bonofiglio R. Active compounds extracted from extra virgin olive oil counteract mesothelial-to-mesenchymal transition of peritoneal mesothelium cells exposed to conventional peritoneal dialysate: in vitro and in vivo evidences. J. Nephrol. Vol. 30 (6), pp. 1-10, 2016.

[10] Demosthenes B. Panagiotakos a, Christos Pitsavos b, Fotini Arvaniti c, Christodoulos Stefanadis, Adherence to the Mediterranean food pattern predicts the prevalence of hypertension, hypercholesterolemia, diabetes and obesity, among healthy adults; the accuracy of the MedDietScore. Preventive Medicine. Vol. 44, pp. 335-340, 2007.

[11] International Olive Oil Council Trade Standard Applying to olive oils and olive-pomace oils. COI/T.15/NC no. 3/Rev1, 5 December, 2003.

[12] Quaglia G., Paoletti F., Finotti E., Beye C. and Raffo A. Antioxidant role of minor compounds in vegetables with particular attention to oils. Recent Researchs Development in Nutrition Research. Vol. 2, pp. 91-112, 1998.

[13] Cappelli P. and Vannucchi V. Principi di Chimica degli Alimenti. ed. Zanichelli Bologna, Italy 2016 ch. 23, pp. 411-421.

[14] Schrfder H. Protective mechanisms of the Mediterranean diet in obesity and type 2 diabetes. Journal of Nutritional Biochemistry. Vol 18 , pp. 149-160, 2007

[15] Moreno J. J. Effect of olive oil minor components on oxidative stress and arachidonic acid mobilization and metabolism by macrophages; RAW 264.7. Free Radical Biology \& Medicine. Vol. 35, n. 9, pp 1073-1081, 2003

[16] Owen W.R., Mier W., Giacosa A., Hull W.E., Spiegelhalder B., Bartsch H. Phenolic compounds and squalene in olive oil: the concentration and antioxidant potential of total phenols, simple phenols, secorridoids, lignans and squalene. (2000); Food and Chemical Toxicology 38. 647-659.

[17] Huisman M.M.H., Schols H.A. and VoragenA.G.J. Changes in cell wall polysaccharides from ripening olive fruits. Carbohydrate Polymers. Vol. 31, pp. 123-133, 1996.

[18] Benincasa C., La Torre C., Plastina P., Fazio A., Perri E., Caroleo M.C., Gallelli L., Cannataro R. and Cione E. Hydroxytyrosyl Oleate: Improved Extraction Procedure from Olive Oil and By-Products, and In Vitro Antioxidant and Skin Regenerative Properties. Antioxidants. Vol. 8, pp. 233, 1-10 2019

[19] Rotondi A., Bendini A, Cerretani L., Mari M., Lecker G., Toschi T. G. Effect of olive ripening degree on the oxidative stability and organoleptic properties of $\mathrm{Cv}$ Nostrana di Brisighella extra virgin olive oil. J. of Agricoltural and Food Chemistry. Vol. 52, pp. 36493654, 2004

[20] Beltran G., Aguilera M. P., Del Rio C., Sanchez S., Martinez L. Influence of fruit ripening process on the natural antioxidant content of Hojiblanca virgin olive oils. Food Chemistry. Vol. 89, pp. $207-$ $215,2005$.

[21] Gutierrez F., Jimenez B., Ruiz A., Albi M.A. Effect of olive ripeness on the oxidative stability of virgin olive oil extracted from the varieties picual and hojiblanca and on the different components involved. J. Agric. Food Chem. Vol.47, pp. 121-127, 1999.

[22] Finotti E., Paoletti F, Bertone A, Galassi P and Quaglia G. Antioxidant capacity determination of extra virgin olive oils unsaponifiable fraction by crocin bleaching inhibition method. Nahrung. Vol. 42, n. 5, pp. 324-325, 1998

[23] Gharsallaoui M., Benincasa C., Ayadi M., Perri E., Khlif M., Gabsi S. Impact of Olives Storage and Irrigation with Treated Wastewater on the Oil Quality: Simulation of olive Mill Conditions. Int. J. of Sustainable Water and Environmental Systems. Vol. 5, pp. 51-57, 2013.

[24] Kiritsakis, Apostolos \& Nanos, G \& Polymenopulos, Z \& Thomai, T \& M. Sfakiotakis, E. Effect of fruit storage conditions on olive oil quality. Journal of the American Oil Chemists' Society. Vol. 75, pp. 721-724, 1998.

[25] Clodoveo M. L. Delcuratolo D., Gomes T., Colelli G. Effect of different temperature and storage atmospheres on Coratina olive oil quality. Food Chemistry. Vol. 102, pp. 571-576, 2007.

[26] Poiana M., Mincione A. Fatty acids evolution and composition of olive oils extracted from different olive cultivars grown in calabrian area. Grasas y Aceites. Vol.55, pp. 282-290, 2004.

[27] Muzzalupo I., Chiappetta A., Stabile G., Bucci C., Perri E. Intravarietal difference of 'Carolea' olive assessed by molecular markers. Acta Horticolturae. Vol. 918, pp. 771-776, 2011

[28] Piscopo A., De Bruno A., Zappia A, Ventre C., Poiana M. Data on some qualitative parameters of Carolea olive oils obtained in different areas of Calabria (Southern Italy). Data in Brief. Vol. 9, pp. 78-80, 2016.

[29] Piscopo A., De Bruno A., Zappia A, Ventre C., Poiana M. Characterization of monovarietal olive oils obtained from mills of Calabria region (Southern Italy). Food Chemistry. Vol. 213, pp. 313 318,2016 
[30] Coseteng M.Y, C.Y Lee C.Y. Changes in apple polyphenolxidase and polyphenol concentration in relation to degree of browning. J. of Food Science. Vol 52, n. 4, pp. 985-986, 1987.

[31] Bors W., Michel C., Saran M.; Inhibition of bleaching of the carotenoid crocin, a rapid test for quantifying antioxidant activity. Biochimica et Biophysica. Acta. Vol. 796, pp. 312-319, 1984.

[32] Finotti E., Beye C., Nardo N., Quaglia G., Milin C., Giacometti J., Physico-chemical characteristics of olives and olive oil from two mono-cultivars during various ripening phases. Nahrung/Food. Vol 45 , n. 5, pp. 350-352, 2001.

[33] Acquistucci R., Melini V., Carbonaro M, and Finotti E. Bioactive molecules and antioxidant activity in durum wheat grains and related millstream fractions International Journal of Food Sciences and Nutrition. Pp 1-9, 2013.

[34] Ordoudi S.A. and Tsimidou M.Z. (2006) Crocin Bleaching Assay (CBA) in Structure-Radical Scavenging Activity Studies of Selected Phenolic Compounds. J. Agriculture and. Food Chemistry. Vol. 54, pp. 9347-9356, 2006.

[35] Mingrone G., Greco A.V., Finotti E., Passi S.;Free fatty acids a stimulus for mucin hypersecretion in cholesterol gallstone biles. Biochimica et Biophysica Acta.Vol. 958, pp. 52-59, 1988.

[36] European Commission Regulation n. 2568/91 of 11 July 1991

[37] Finotti E, Bersani A.M., Bersani E. Total quality indexes for extravirgin olive oil. J. of Food Quality. Vol.30, pp. 911-931, 2007.

[38] Finotti E., V., Bersani E., Vivanti V.,Friedman M. Application of a Functional Mathematical Index to the evaluation of the nutritional quality of potatoes. Food 3 (special issue 1), pp. 30-36, 2009.

[39] Finotti E., Bersani E. and M. Friedman. Application of a Functional Mathematical Index for Antibacterial and Anticarcinogenic Effects of Tea Catechins, J Agriculture and Food Chemistry. Vol. 59, pp. 864869,2011

[40] Finotti, E. Bersani, V. Vivanti and M. Friedman Application of a functional mathematical quality index to asparagine, free sugar and phenolic acid content of 20 commercial potato varieties. Journal of Food Quality. Vol. 34, pp. 74-79, 2011.

[41] Finotti E., Bersani E., Del Prete E., Friedman M. A functional mathematical index for predicting effects of food processing on eight sweet potato (Ipomoea batatas) cultivars. J. of Food Composition and Analysis. Vol. 27, pp. 81-86, 2012.

[42] Finotti E., Bersani A., Bersani E. and Del Prete E. Functional Mathematical index (FMI): An index generator for "Taming" quality applied to food and processes. In Chloe M. Gagne and Daniel B. Jones Processed Foods Quality, Safety Characteristics and Health implications. New York, USA: Nova Publishers, 2013, ch 5, pp. 107138. 